\title{
Managing the Agricultural Sector Through Muzara'ah: Implementing an Islamic Economic Participatory Mode of Financing
}

\author{
Amjad Ullah Jan Bangash \\ Head of Shari'a \& Secretary to Shari'a Board \\ Muzn Islamic Banking National Bank of Oman, Oman \\ E-mail: islamicbankerbychoice@gmail.com
}

\begin{abstract}
The tremendous growth of Islamic banking has transformed a relatively new industry into a robust and widespread reality on the ground. Several Islamic financial institutions (IFIs) operate in different countries of the world and several Islamic modes of financing have been developed; however, most cater to the needs of commercial businesses, and personal finance. Few IFI products have been made available to support the agricultural sector. One rarely used product is Salam (a kind of sale in which farmers sell their product in advance, before the season's harvest, to get funding for farming inputs as well as for their livelihood expenses), which, however, is of limited use due to a range of limitations. Hence, there remains a need for a product which is shari' a compliant and acceptable to IFIs as well as the end users, that is, the farmers. This paper proposes an Islamic model suitable for entrepreneurs, farmers and IFIs. A mixed-methods research methodology is applied: while the study is mainly qualitative, a quantitative approach was applied to the data obtained through questionnaires. The general finding of this paper is that there is a need to have a shari' a-compliant financing model to be based on a participatory basis, in place of the debt-based modes which are currently in extensive use by IFIs. Therefore, I selected the Muzara'ah (sharecropping) concept as the basis of a model to help the agricultural economy and the Islamic banking industry. The reason for choosing the participatory over the debt-based mode is that the latter cannot bring about any real change, as I shall demonstrate from the particular perspective of Pakistan. Research into the demography of the Pakistani agricultural sector, on the other hand, demonstrates that the Muzara'ah model can be used anywhere in the world. The paper also aims to understand the effects on this sector of the use of financing by both commercial and Islamic banks, the strengths and weaknesses of financial intermediation, and the challenges faced by Islamic banks as concerns financing the agricultural sector. This research paper is divided into four sections. The first introduces and debates the position of agriculture in Pakistan; the ways in which commercial banks extend loans to this sector, and the socioeconomic effects of such loans; and the different existing financing models being used for this sector and their respective drawbacks. The section also presents a brief discussion of Islamic banking and its advantages; different Islamic modes of financing; and how Islamic banks are supporting the agricultural sector in Pakistan. Furthermore, it argues that there is a global need for an alternative Islamic model to finance the agricultural sector, and that this need is particularly pressing in Pakistan.

The second section discusses the Muzara'ah model, through an extensive review of the extant Islamic literature, encompassing, but not limited to, the definition of Muzara'ah, the Islamic basis for the practice and Islamic juristic views, as well as how Muzara'ah worked in a previous age. Moreover, this section discusses the similarities and differences in opinion among Islamic jurists (experts in Islamic law) about the validity of Muzara'ah. The focus of this section is on finding a consensus as to the most common and viable mode of Muzara'ah which is acceptable to a majority of jurists. The third section surveys agriculture in Pakistan, as well as the opinions and perspectives of farmers, bankers and other stakeholders to inform the proper development of an Islamic Muzara'ah sharecropping model. Practical research was carried out in Kohat, one of the cities of Pakistan, which is famous for its guava, wheat and maize production. A description of the fieldwork is also presented in this section. The fourth section draws on all the above information to develop a model based on the concept of Muzara'ah which can be feasibly implemented in the Islamic banking industry. Moreover, it presents a discussion of the strengths and weaknesses of the model and provides suggestions and recommendations about how it should be rolled out. The needs of end users, such as farmers and growers, are addressed, and a discussion is presented of how the product better meets their needs than the other products which are currently available to them.
\end{abstract}

Keywords: Agricultural Sector, Muzara'ah, Islamic Economic, Mode of Financing.

\section{Introduction}

\section{I.I Statement of The Problem}

The research will analyse the views of prominent Islamic legal jurists on Muzara'ah. Moreover, it will examine the use of sharecropping and similar modes of working which have been practised in the agricultural sector and ascertain whether they are shari'a compliant. The outcome of the research is a model based on the concept of Muzara'ah, along with the general guidelines 
which must be followed to ensure it is acceptable under Islamic guidelines and can be adapted for use by the current Islamic banking industry.

As a research statement problem, the research will first briefly analyse the agricultural sector of Pakistan, in particular examining how it is performing with the assistance of interest-based loans from financial institutions; whether any Islamic bank has made finance available to this sector; the overall impact of the lending; and whether a need exists for a Muzara' ah model to help the sector.

Islamic economic principles lay more emphasis on participatory modes of financing, such as Musharaka (a kind of partnership in which all partners contribute capital, profit is shared as per agreed ratio and loss is shared as per investment amount); and Mudaraba (a kind of partnership in which one partner contributes equity and other partner provides skills; profit is shared as per an agreed ratio while any loss is borne by the capital provider) than on debt-based modes such as Murabaha (a kind of sale in which the seller discloses both cost and profit), Ijarah (a kind of lease ending with ownership transfer) or Istisna (an order to manufacture goods).

\section{I.2 Background and History}

Muzara'ah models of financing are available under varying names and under different methodologies in different countries. I have personally witnessed the use of this financing model in Pakistan; however, such Muzara'ah modes are not acceptable under Shari'a for several reasons, the principal being that such models require a lump sum amount to be fixed in advance, without waiting for a final outcome.

According to Mohsin (2005), the use of Muzara'ah as applied by Islamic banks in Sudan is based on the concepts of Musharaka and Mudaraba. Under Musharaka, the model takes one of two forms. The first form of Musharaka is executed when banks provide small farmers with fixed assets such as tractors, ploughs, water pumps and inputs (e.g., seeds, fertilisers and pesticides). Farmers in turn contribute their land, labour, and part of the running expenses and management, and the profit or loss is shared according to share of equity after the management services rendered by the farmers have been deducted. Under the Mudaraba model, on the other hand, the banks only provide the funding. The farmers use their skills to produce the outcome, which is shared as set out in the agreement.

A few other examples of sharecropping or agricultural financing, either undertaken by IFIs or otherwise termed Islamic, are in practice in countries like Malaysia, Nigeria and Indonesia, as outlined in later sections.

\section{3 Justification of the Problem}

Firstly, very little research has been carried out on Muzara'ah; secondly, the models in local use in Pakistan cannot truly be described as Muzara'ah. Thirdly, no Islamic financing entity is currently practising a Muzara'ah-based model for agricultural financing, as most Islamic financing products in use are debt-based. Indeed, significant criticism has been made of the fact that the current Islamic banking industry is wholly based on debt-based modes of financing, rather than the trade- or participatorybased modes which are among the most important characteristics of Islamic economics, given that Islam encourages partnership and discourages debts. This research paper aims to provide a framework for an Islamic participation model based upon the Muzara'ah model acceptable under Islamic guidelines, which will be effective for the Islamic banking industry, productive for farmers and positive for the whole economy.

\section{I.4 Literature Review}

Lack of financing is one of the main reasons that development has been lacking in the agricultural industry. Neither the Islamic nor the conventional banking system provides intensive funding to the agriculture sector for several reasons, including the risk posed by agriculture, incompatible sources of financing, a lack of banking experts, and the fact that the agriculture sector has been historically marginalised.

There are three main concepts of agriculture under Islam: I) Islam encourages people to be involved in agricultural production, since it is the easiest way to gain good rewards while earning a beneficial and permissible income; 2) Islam encourages the provision of food for people as part of fulfilling their needs; and 3) Islam discourages any agricultural activities which are carried out for doubtful or invalid purposes.

No text explicitly describes the concept of Muzara'ah in the primary books of Fiqh (The Holy Book Quran and the authentic sayings of the last Messenger of Allah, Muhammad (Peace Be upon Him (PBUH)). However, an incident which occurred in the time of the Prophet Muhammad (PBUH) has been correlated to Muzara'ah by most Islamic legal experts. The Prophet Muhammad (PBUH) is reported to have given the land of Khaybar to its inhabitants to work on and cultivate in return for half of its yield (fruits and plants) ${ }^{\mathrm{I}}$. This will be discussed in detail in later chapters (Accounting \& Auditing Organization for Islamic Financial Institutions (AAOIFI), 2015 p.I I88).

According to Kahf (2015), "the word Muzara'ah'ah is derived from root word (zara) which means to plant or to cultivate. It generally applies to agricultural products. The English meaning of Muzara'ah'ah is crop-sharing” (pp.I46-I47). 
Generally, we can say that Muzara'ah is a kind of partnership in agricultural production whereby two or more parties agreed to contribute land, labour and agricultural inputs to share the gross yield according to a pre-agreed ratio after harvest.

\section{I.5 Theoretical Framework}

Since the current research is doctrinal in nature, a critical and detailed analysis will be made of the literature available on Muzara'ah. Moreover, comparisons of Muzara'ah with local sharecropping modes, as well as similar Islamic modes of financing, will also be reviewed in detail.

The following conceptual framework has been formulated to support the research:

- The guidelines available in the Fiqh literature;

- Islamic jurists' views of Muzara’ah in general;

- Local sharecropping arrangements;

- Similar modes of Islamic finance in current use by the Islamic banking industry to promote this sector; and

- Whether any mode of Muzara'ah can be developed which is acceptable under shari'a and to the Islamic banking industry.

This study aim is to develop a model based upon the concept of profit sharing which is shari' a compliant and can be used by the industry. In order to evaluate and finalise this model, we shall briefly review the performance of the agricultural sector of Pakistan, the impact of debt-based policies and debt-based products used by the government and financial institutions, respectively, in this sector. The study will also look into whether Islamic financing is available to this sector.

In order to develop a participatory model, the relevant mode in shari'a is Muzara'ah so this study will also review the related classical literature and the opinions of different Islamic jurists in this regard.

This research also aims to briefly review the availability and use of local sharecropping models and their compliance with shari'a guidelines. This matter will be determined through a practical survey of an agricultural area in Pakistan, discussion with local farmers and Islamic bankers. The concluding part will address the suitability and adoptability of a shari'a-compliant Islamic participation model (Muzara'ah) of Islamic banking, whether the need for such a model exists and, if so, whether a suitable model can be developed which is practical and acceptable to different stakeholders.

\section{I.6 Methods and Procedures}

Both qualitative and quantitative methods and procedures were used to complete the research paper. Qualitative methods were applied to the data extracted from different sources to understand agricultural output and lending by the banks to this sector. Data were mostly obtained through the websites of the banks concerned. The qualitative research also included a review of the literature available on this topic and of the use of Islamic models in the agricultural sector. Quantitative methods and procedures were also adopted by directly interviewing Islamic banking staff, farmers and agricultural experts and interpreting their responses to obtain the findings.

\section{Data Analysis}

\section{I. Background - Financing the Agricultural Sector in Pakistan}

Pakistan's agricultural sector plays a central role in the economy as it contributes I8.9 percent to GDP and absorbs 42.3 percent of the labour force. It is also an important source of foreign exchange earnings and stimulates growth in other sectors. Pakistan has one of the highest proportions of irrigated cropped area in the world. It has two principal crop seasons, namely the "Kharif", in which crops are sown in April-June and harvested during October-December; and the "Rabi", in which sowing takes place in October-December followed by harvesting in April-May (Pakistan Economic Survey, 20I7-I8).

The agricultural sector was once the backbone of the Pakistan economy, upon which the government of Pakistan relied for its foreign exchange and revenue. However, agricultural productivity has continually decreased, for several reasons, one of which is that lending is based on high interest rates, without any financial or social intermediation. Although Pakistan used to export a range of agricultural produce to many countries, now the country finds itself dependent on imports to feed its growing population. The government of Pakistan has tried various ways to help this sector; however, it has met with limited, if any, success. Normally, agricultural financing incurs higher interest rates than the financing offered to other sectors. Among the reasons for this is that the risks are considered particularly high. We know that banks always base their approach to lending on risks and that they have to create significant provisions, which has a negative impact on the bank's profitability; therefore, lending at higher interest rates cannot be effective for the wellbeing of farmers, for the banks themselves, or for the economy of Pakistan. The Pakistan Bureau of Statistics (n.d.) indicates that the majority of the Pakistani population, directly or indirectly, are dependent on the agricultural sector, which still contributes about $24 \%$ of the Gross Domestic Product (GDP), accounts for half of the employed labour force and feeds the entire rural and urban population.

Pakistan's largest food crop is wheat (Business Recorder, 20I I; Pakistan Bureau of Statistics, (n.d.)). In 2005, Pakistan produced 2I,59I,400 metric tons of wheat, more than the whole of Africa (20,304,585 metric tons) and nearly as much as the whole of South America (24,557,784 metric tons (IBP, 20I5), and harvested more than 25 million tons of wheat in 2012. 
Pakistan is a net food exporter, except in occasional years when its harvest is adversely affected by droughts. It exports rice, cotton, fish, fruit (especially oranges and mangoes) and vegetables, and imports vegetable oil, wheat, pulses and consumer foods. The economic importance of agriculture has declined since independence, when its share of GDP was around 53\%.

Following the poor harvest of 1993, the government of Pakistan introduced agriculture assistance policies, like subsidies, support prices (higher than sale prices) and measures to increase wheat and oilseed production, and directed commercial banks to prioritise lending to this sector. In spite of all these efforts, real growth in the agricultural sector has not increased.

\subsection{Lending to The Agricultural Sector by Commercial Banks}

The government of Pakistan focuses on the agricultural sector and continuously devises policies and strategies to increase its growth. Every effort is being made to provide the direly needed credit to the farming community through a well-established infrastructure of conventional banks. Currently, 20 banks with around 3,700 agriculture-designated branches are facilitating farmers by extending agriculture credit throughout the country. During the period July 2010 to March 20II, the banks disbursed a total of Rs. I68.7 billion (I.98 billion USD approximately) (Raza, Saeed \& Shahid, 2013). However, despite all these efforts, the agricultural sector lost significant momentum, with growth slowing to $2.7 \%$ in the decade of 2000 s as against $4.4 \%$ in the 1990 s and $5.4 \%$ in the I980s (Raza, Saeed \& Shahid, 2013). In exercise of the powers vested in the SBP, under Section 25 of the Banking Companies Ordinance 1962, an Agricultural Loans Scheme was introduced due to the absence of developed and specialized institutions for the agricultural sector. Commercial banks which have large networks of branches were advised to lend mandatory agricultural financing under this Scheme (Raza, Saeed \& Shahid, 20I3). Since July 28th I997, the SBP has removed the cap on the minimum lending rates to be charged by commercial banks on agricultural financing. The cap on maximum lending rates was removed in October 1995, since when banks have been free to charge mark-up from borrowers on a competitive basis determined under market forces. The SBP is authorized to determine the policy in relation to advances to be followed by the banks in general or by any bank in particular (Raza, Saeed \& Shahid, 20I3).

In spite of all of the efforts of government and the private sector to promote agriculture through the various measures described above, the sector is still facing many challenges. Solutions suggested to remedy these challenges have been to little avail. The current research hypothesises that the main reason for this failure is that all the financing measures taken by government are based on interest-based lending, which has proven to be an incorrect approach. This research paper focuses only on financial intermediation through interest-based lending and will not cover other factors such as the education of the farmers, political hurdles, or government lack of interest in the agricultural sector.

\subsection{Overall Effects of Interest-Based Lending}

In interest-based lending, funds are provided on the basis of collateral, with no consideration given to their end use. This results in negative production as there is a chance that the funds will not be utilized for the right purpose. Moreover, it encourages people to live beyond their means: rich people do not borrow for productive projects only, but also for conspicuous consumption.

In countries like Pakistan, where there different political powerful personalities, strong feudal lords, and sugar cane and wheat cartels which are usually part of government, it is said that part of governmental borrowing is not dedicated to genuine economic-based requirements; rather, it is allocated to lavish non-developmental expenditure and projects motivated by political ambition instead of a real plan to increase economic growth. Such borrowings only accrue interest-based debts, and injustice is one of the elements present in an interest-based system. It affects both borrowers and lenders but mostly borrowers, who are normally farmers in agricultural-based lending. Interest brings injustice to the borrower, if he or she suffers a loss, and to the lender, if the debtor earns huge profits. The commercial banks accept depositors' money and lend it to borrowers. Simply put, banks are places where the money of many is kept in the hands of few.

Most commercial firms are mostly financed by banks using depositors' money. The banks pay very low rates on deposits while charging very high rates on loans. The injustice is done to depositors by their having to agree to low rates, while it is done to borrowers as they have to pay high interest rates, resulting in the total collapse of the system. Borrowers can also earn huge profits; however, they pay only a small amount of interest and most of that small portion is kept by banks. Very little is repaid to depositors in the shape of interest, even though they had a greater input in the progress of the business than the actual owner and bank. Hence, the largest rewards are secured by the big entrepreneurs whose real contribution to a business in terms of money is minor. The net result in such cases is that all the profits of big enterprises are earned by persons whose own financial input does not exceed 10\% of the total investment, while the people whose financial contribution was as high as $90 \%$ get nothing in real terms, because the interest due to them is often repaid through the increased prices of the products. Therefore, in a number of cases this return becomes negative in real terms. Conversely, banks' lending rate is much higher for poor customers, including farmers, who have great difficulty in paying the interest.

Since interest-bearing loans have no specific relation with actual production, and the lender, after securing a strong collateral, normally does not care how the funds are used by the borrower, the money supply effected through banks and 
financial institutions is unconnected to the goods and services actually produced on the ground. This situation creates a serious mismatch between the supply of money and the production of goods and services, which is obviously one of the basic factors that create or fuel inflation.

In an interest-based debt contract, a borrower has to repay the principal plus an additional sum, the interest, during a fixed timeframe. This is against the nature of the business for which funds are needed and its financing, since a debt contract establishes the legal right of a lender to receive more money in the future in exchange for a given amount of principal today-an exchange of spot money for more future money-regardless of the outcome of the project undertaken by the investor entrepreneur. Indeed, if the risks of informational problems and associated monitoring costs are priced into the loan contract, then all risks are shifted to the entrepreneur.

\subsection{Alternative to Interest-Based Lending - Islamic Finance}

Islamic finance, being based on sharing the risk of an activity rather than on interest-rate-driven debt contracts, contributes efficiently to capital accumulation and is immune to financial instability and speculation. The objective of Islamic finance is to promote sustained growth and full employment, thus contributing positively to poverty alleviation and, ultimately, to economic and social justice.

\subsection{Why Islamic Banks in Particular and Conventional Banks in General Avoid Lending to The Agricultural Sector}

Lack of both financing and participation is among the main reasons that agriculture cannot be developed further in Pakistan and other countries. This is a built-in phenomenon: Islamic and conventional banking systems are uninterested in financing the agricultural sector for a range of reasons, including the risk of agriculture, incompatible sources of financing, and lack of banking experts who know about farming and the people involved.

\section{Muzara'ah in Detail \\ 3.I What is Muzara'ah?}

Muzara'ah is Arabic for sharecropping: a partnership in crops whereby one party (the landowner) presents a piece of land to another (the agricultural worker) for the latter to cultivate and maintain in return for a common defined share in the crop. In essence, muzara'ah' also encompasses the concept of shirkah (partnership).

Normally, Muzara'ah partnerships concern agricultural production, whereby two or more parties provide land, labour and agricultural inputs. They then share the produce as per predetermined percentages.

\subsection{How Muzara'ah Differs from Similar Islamic Modes of Financing}

According to Kahf (20I5), Muzara'ah has two derivatives, Musaqah and Mugharasah, all of which share objectives, conditions, and general characteristics. Kahf (2015) differentiated the three as follows: Muzara'ah is a crop partnership between a landowner and a farmer; Musaqah is a fruit partnership between an owner of fruits and a farmer; and Mugharasah is a fruit, trees and land partnership between an owner of barren land and a farmer. Musharaka differs from Muzara'ah as in Musharaka the profit distribution is on a net revenue basis while in Muzara'ah, it is on a gross revenue basis. Moreover, in Muzara'ah, there is no need for any liquidation of assets or goods. Land, as the main fixed asset, goes back to its owner; machines also go back to whoever contributes them after the gross products are distributed according to the contractual ratio (Kahf, 2015).

\subsection{Sharecropping Practices Elsewhere in The World}

- Arabs, particularly the people of Medina, have practised a crop sharing system known to be Muzara'ah since before the advent of Islam; later, the Prophet PBUH and His companions practised it also (Al-Qurafi, I285/684AH (I994))

- In Selengor, Malaysia, under the practice of Muzara'ah farmers share the costs of paddy planting with the landowner, who contributes through the sharing of seeds, fertilisers, pesticides, transport and labour costs in seeding and ploughing. Some fixed rent paid for the land is also involved in the sharecropping model, which is not a feature of Muzara'ah (Rahman \& Othman, 2012).

- In Malaysia, there are few Islamic banks or Islamic counters within conventional banks that offer Islamic financing facilities for the agricultural sector or Islamic models of financial practice other than Muzara'ah.

- In Sudan, the Sudanese Islamic Bank (SIB) adopted three different models of Muzara'ah financing partnership: (I) canal irrigation, (2) pump irrigation and (3) rain-fed irrigation. The SIB provides fixed assets, such as tractors, ploughs, harrows, water pumps and inputs (e.g., seeds, fertilisers and pesticides), fuel and jute sacks, as well as comanagement, marketing, storage and extension. The farmer, on the other hand, contributes his or her land, labour and part of the running expenses and management. The farmer receives $30 \%$ of the net profit for management while the remaining $70 \%$ is divided between the SIB and farmer according to their equity share (Al-Harran, I990). 


\subsection{Local Cost-Sharing Models}

During my research on this subject, I personally visited Kohat region of Pakistan. I observed that a similar practice is also in use, which may be termed "local sharecropping". Under this practice, the landlord (normally a wealthy person) offers her or his land to a landless farmer to cultivate and share the produce according to the local tradition of the people. (However, it is observed that the landlord always receives a fixed sum of money in advance without waiting for the result of harvesting). The amount is be paid by the farmer, whether crops are produced, sold or destroyed. This local sharecropping model cannot not be termed Muzara'ah since it has an element of fixed return which does not correspond to agricultural production, while Muzara'ah is always linked with the outcome of agricultural production.

\subsection{Islamic Jurists' Views on Muzara'ah}

The opinions of Islamic jurists differ widely regarding Muzara'ah. Some allow it, some disallow it, and some allow as long as it meets certain conditions. Imām Abū Ḥanīfa rejected both Muzara'ah and Musaqat contracts because he considered that the underlying contract in the case of Muzara'ah is actually an Ijarah (Kāsānī I968; 3808; Ibn Humām n.d.; 32). Imām Abū Haniffa based his opinion on the Kharaj (tax) imposed on the Jews by the Prophet PBUH as he believed that the underlying contract between the Prophet PBUH and the Jews of Khayber was neither participatory nor a partnership; hence, it could not be Muzara'ah, which must have an element of one of these (Kāsānī I968; 3808; Ibn Humām n.d.; 32). Hence, the Prophet PBUH only enforced a kind of tax over the lands of the Jews in Khayber. Moreover, Imām Abū Ḥanífa believed Muzara'ah is not valid because merely owning bare land is not a basis for entitlement to profit since the land is not liable to any loss; partnership, on the other hand, comprehends the element of profit and loss so land cannot be the subject of a Muzara'ah contract (Nyazee, 2002, pp.280-28I).

Imam Malik and Imam Shafi consider Musaqat valid but Muzara'ah invalid on the grounds that Muzara'ah is an unpredictable and improper transaction involving uncertainty and a sale at yet unknown future values (Shafiai, 20II). However "Imām Mālik (7I2-796) and Imām Shāfi'ì (767 -820) only acknowledged the principle of Muzara'ah if it was a derivative from a contract of Musaqat (Irrigation sharecropping)" Shafiai (201I, p: 190). They infer their theory of Musaqat based on the transaction between the Prophet (PBUH) and the Khaybar tenants, which mainly involved date palms forming the capital. Therefore, they consider Musaqat as a partnership contract, wherein the capital provider advances his capital to the worker and the profit will be shared as stipulated. In addition, Imām Shāfi ${ }^{'} \overline{1}$ opposed the opinion of Abū Yūsuf who considered bare land in al-muzāra'a to be equal to capital in al-muḍāraba contract. He argues that in al-muzāra'a, there is nothing on bare land which could be used or be shared between landowner and farmer and this would involve gharar (risk/uncertainty), which is prohibited in Islamic law. There is no fruit or output which may be apportioned to both parties like profit distribution in almuḍāraba (Shīrāzī 1959). On the other hand, Imām Mālik and Imām Shāfi'ī permitted the renting of land (Ijarah) and considered the sharecropping contract as a form of Ijara. There is one deviation as Imām Shā $\mathrm{f}^{i} \overline{\mathbf{1}}$, however, recognized the legitimacy of Muzara'ah, but only when it was subordinate to Musaqat. For example, there must be some fruit-bearing trees on the land or the land should be between two groves that are part of the Musaqat contract (Shāfìì, I993, pp. I3-I4; Abd Allāh Fațānī, n.d., I06). According to Imām Shăfi' ${ }^{\prime} \mathbf{i}$, on the one hand, sharecropping which involves the irrigation of date palms and grape vines (Musaqat) is valid on the grounds of the Prophet's (PBUH) action at Khaybar (Donaldson, 2000). On the other hand, sharecropping on arable land with no perennial crops is what the Prophet (PBUH) prohibited as Muzara'ah (Donaldson, 2000).

Imām Abū Yūsuf and Muhammad al-Shaybānī consider both Muzara'ah and Musāqāt to be valid, as they are a partnership between property and work, which is thus deemed permissible in analogy to Mudaraba (Shawkānī 1978, pp.I5-16]. In this regard, Abū Yūsuf compares the bare land in Muzara'ah to the capital in the Mudaraba contract based on qiyās (reasoning/analogy). Abū Yūsuf and al-Shaybānī also stated that the seed contributed by the landowner should be considered as his capital, and his land should be assigned the status of real estate, because of which additional profits have been permitted in regular partnerships based upon labour (sharika al-'amal), whether 'inān or mufāwaḍa (Nyazee 2002, pp.280-28I). The Hanafite jurists accept the opinions of Abū Yūsuf and al-Shaybānī and declare Muzara'ah to be valid on the basis of istihsān. The basis of their istihsān is that the Muzara' ah contract is sanctioned by the 'recognised custom of people in all countries' ('urf ') (Johansen, 1988, 54). Abū Yūsuf and al-Shaybānī also listed the types of Muzara'ah contract which were valid. First, the land, implements (machines), seeds and animals are provided by the landowner and the work (effort) is undertaken by the tenant. Second, the land is provided by the landowner and the rest is provided by the tenant. Third, the land and seed are from the landlord and the rest from the tenant. However, if the land and implements (machines) are provided by the landowner and tenant provides the seeds and the work, this type of contract is considered invalid (Kāsānī I968, pp. 38I6-38I9).

Ahmad ibn Hanbal concludes that Muzara'ah for one third or one fourth of the crops is valid in law. He also suggests that if the seeds are supplied by the landlord, and the sharecropper contributes his labour and draught animals, he is like the worker who works and expends his labour using the capital supplied by the owner (Ibn Qudāma n.d.). Aḥmad ibn Ḥanbal also applies the 
analogy of the principle of Mudaraba Muzara'ah, viewing land as the capital of the owner, and thinks that the land of Khaybar contained more date palms than bare land; hence the Prophet (PBUH) provided this land under a contract of musāqāt (Ziaul Haque, 1984).

Ibn Taymīya considers Muzara'ah as a partnership in land cultivation and not a case of lease, and likens it to a kind of Mudaraba (Shafiai, 20II). Ibn Taymīya regards land as a factor that enables production, so it can be employed for production, in the same way as money (capital) (Shafiai, 20II). He also says that the resulting crop is a product of land that consists of soil, water and air, of the physical use of labour (labour and organization) and of bullocks, and means (capital) (Shafiai, 20II). Moreover, Ibn Taymilya argues that sharecropping is not a 'speculative' hire where one party secures benefit while the other is exposed to chance (Shafiai, 20II). According to him, if there is no crop, the landowner cannot take anything from the cultivator, since the contract does not entitle him to it (Shafiai, 20II). While one party loses the fruits of his labour, the other loses the yield from his land, so both parties receive nothing. Ibn Taymīya says that the risk involved in Muzara'ah and Musaqat is unlike the risk in gambling because in these contracts both gain and loss are shared by both parties (Shafiai, 20II). Ibn Taymīya also analyses Muzara'ah in the light of hadīth, and says that the Prophet (PBUH) himself entered into a contract of Muzara'ah (Shafiai, 20II). He proves that the prohibition reported by some groups who said this contract is invalid is not absolute. Only those kinds of sharecropping are prohibited where one party makes it a condition that he will get a specific quantity of the product; or that the product of some particular part of the land (fertile area) will go to him (Shafiai, 20I I).

Ibn Hazm explains that Muzara'ah does not belong to the category of Ijara. He allows Muzara'ah only when the rights of the tenant are protected and she or he is not left at mercy of the landlord. The tenant must get her or his due share from the crop whether the crop is plentiful or inadequate. For Ibn Hazm, the contract of Muzara'ah is not valid for a fixed period of time, as according to him, the Prophet (PBUH) and Companions never fixed any period of time for this contract. Both the tenant and the landlord are free to terminate the contract (Ziaul Haque, 1984).

\subsection{Concluding Remarks}

it is deduced from the above viewpoints of Islamic jurists, that the Muzara'ah concept is accepted or rejected due to some discrepancies found and if such discrepancies are removed then the concept is acceptable. The following are among the features which must be properly addressed to make this concept acceptable.

- Gharar (excessive uncertainty) must not be present in the sharecropping contract, as it leads to dispute.

- There must NOT be any condition in the contract whereby one party has an unfair advantage over the other.

- There must be an agreed sharing ratio of the outcome of Muzara'ah, that is, a sharing ratio to distribute crops and revenue.

- There must be an agreement about the partners' contribution and distribution of gross revenue.

- The land must have some use; land which cannot be used for cultivation cannot be subject to Muzara'ah. There should be some plan available to use the land for the purpose of Muzara'ah.

\section{The Practice of Muzara'ah And Similar Modes - A Practical Study in Kohat, Pakistan 4.I Use of Financial Intermediation}

I selected the region of Kohat, which is famous for guava, wheat and maize. Of these crops, I selected maize, which is found in many areas of Kohat, such as Darsamand, Thall and Doaba. The purpose of the study was:

- To identify farmers' funding requirements and how funding is obtained by local growers;

- To determine whether any kind of sharecropping contract is in place; and

- To interview the relevant stakeholders and, based upon the interviews carried out, understand how to develop the Islamic Muzara'ah model.

First of all, I undertook a detailed survey of the vast region in which maize is cultivated. Since the education level is so low among the farming communities, it was difficult to draft relevant questions.

Initially, I randomly visited farmers and other possible stakeholders with the help of local relatives. In total, I visited almost 300 different maize farms, hoping to select my final sample of 200 gardeners or farmers from among these. I selected I00; however, after further negotiations and meetings, I shortlisted only IOO as there was a possibility of not obtaining exact or complete information from others because they were unwilling to respond.

Besides this, I engaged in a series of talks with local people, landlords and staff working in Islamic banks.

A questionnaire was designed and shared with the farmers. All the respondents were male and, as most were illiterate, the questionnaire was designed based on their education, skills, status (landowner, landless, farmer of land, farmer without land and certain others) and administered in their native language. In addition to this, informal interviews with bank managers were used as a survey instrument.

Each respondent was required to answer all of the close-ended questions. Their replies were collected and analysed based in percentages. 


\subsection{Questionnaire}

A sample of the questionnaire is available in Appendix A while the replies of the respondents are available in Appendix B. Results are discussed here.

\subsection{Discussion and Findings}

The analysis shows that the majority of respondents are not well educated, have little knowledge of technology, have spent the whole of their life in this profession and are not very satisfied with how production compares to the work they put in. This also shows that there is no concept of sharing the output, which cannot be considered as Muzara'ah in any case, and there is a need for a model based upon participation and financial intermediation which can be achieved through the Islamic participation model based upon the concept of Muzara'ah.

- Most of the farmers need funds to better grow their crops and produce enough fruits from such crops. However, due to the unavailability of easy funding and the difficult procedures required by banks, they experience difficulty in obtaining finance. In fact, $72 \%$ of respondents mention collateral requirements, specifically, that the mortgage on the farm/garden restricts them from applying for loans.

- It is also evident that though the farmers are earning a profit, their earnings are not large: $82 \%$ of the farmers think there is insufficient profitability, which begs the question of why they still grow maize. The answer is that this is the only profession they know and are able to exercise; it allows them to survive, and the climate of Kohat is very suitable for maize farming. However, it is also a fact that most landlords are now selling their lands for the purpose of construction.

- When asked about why they had not applied for commercial loans, 58\% of respondents cited interest-based lending (which has a religious element) while 38\% considered it due to collateral (mortgage on the garden/farm), bearing in mind that in their answers to Question I, 72\% of respondents were not willing to take out commercial bank loans due to collateral issues.

- One hundred percent of the farmers disclosed that they do not use any technology. However, they were also of the view that proper use of technology and other measures can increase output and profitability. The only hazard to maize farms is excessive moonlight and, since the risk is known, it can be minimized by taking certain measures that, of course, need funding. When asked about the purpose of a loan, 60\% mentioned technology or the use of technical measures like soil preparation and segmentation of crops, because this will increase productivity, while $40 \%$ proposed to buy equipment. This means funding is required for some specific purpose and not for related skills.

- Asked about the existence of any local crop sharing arrangement, almost $92 \%$ of respondents responded that it consists of a fixed return paid to the landlord in advance, without taking the production at the end into consideration. Similarly, when asked what they knew of Muzara'ah, 100\% of respondents responded that it consisted of paying a fixed return to the landlord in advance and that whatever happened would be the responsibility of the farmer. This means that the local cost sharing agreement does not meet the guidelines set by shari'a for Islamic Muzara'ah sharecropping. When I explained to the respondents about the Islamic Muzara'ah sharecropping concept, its features and how it works, $80 \%$ liked it while no one disliked it. However, $20 \%$ of the respondents were of the view that it is not practical due to their understanding of the local market and local people, and possibility that landlords might not be interested in profit and loss sharing (PLS).

- When a question about the Islamic Muzara'ah sharecropping concept was put to the landlords who just provide lands to people but do not actually carry out farming activities, 54\% responded that they would not be interested in using this model. This was due to their understanding that they might get less, or even make a loss, as compared to the fixed return model. However, I8\% liked it and 28\% had no idea, which means $46 \%$ may adopt it - a large number taking into consideration that these are landlords.

- Of the staff working in Islamic banks, $65 \%$ had no idea whether their bank would be interested in agricultural financing. This is a general behaviour which shows that Islamic banks are not interested in this type of financing and that such banks do not have a model or product to facilitate this sector. Fifty percent of respondents immediately rejected any financing without collateral or against a personal guarantee and 50\% of the Islamic banking staff did not know whether their bank would be interested in agricultural financing. This shows a lack of Islamic banking interest in agriculture financing due to the element of risk and the unavailability of suitable products.

- Last but not least, the survey shows that most of these farmers are willing to continue, although they do not make sufficient profit, for some of the reasons below:

- This profession is their main source of daily income.

- They want to keep the land they inherited from their ancestors.

- There is a high market demand for maize locally and from abroad. 
From the study, it can be concluded that financial intermediation based upon a sharing model like the Islamic Muzara'ah sharecropping model can help farmers and grow the agriculture sector in Pakistan or any other agriculture-based economy.

The survey also shows that, as regards the role of Islamic banking in the agricultural sector, the respondents somewhat agree that there is a significant relationship between Islamic banks and this sector if Islamic banks create awareness. Moreover, the results show that respondents agree that Islamic Muzara'ah sharecropping will offer easy and helpful terms.

The above research and results of the survey indicate that there is a dire need for agriculture-specific and agriculture-focused models.

Consequently, I provide below the Islamic participation model based upon the concept of Muzara'ah, outlining the necessary conditions, structure, modality, termination and other guidelines which must be adopted by the Islamic banking industry to help farmers and develop this vital sector.

\section{Need to Develop Islamic Participatory Model}

Based on the research and survey, an Islamic participatory model is proposed below to be adopted by Islamic banks or an economy to achieve economic stability. Normally, three situations may arise: a landlord who has land but does not have skills to cultivate crops; a farmer who does not have land but has skills; and a farmer who has land and skills, but no funds. Funding requirements and participation are common elements in all three scenarios.

\section{I Islamic Participatory Model Based on The Concept of Muzara'ah}

Below is the structure of the product once an IFI is ready to enter into such an arrangement after obtaining all of the necessary approvals.

- An IFI enters into a Muzara'ah contract with the relevant parties to provide financing to procure the necessary inputs and logistics related to cultivation.

- Partners' contributions and the ratio of distributing gross revenue are to be defined/agreed in the contract.

- A management agreement is to be executed between the parties where the party who will be actually working in the field will act as Wakil (Agent) to take care of the land and the farming activity.

- The IFI will appoint a farmer who does not have land but has farming skills as the party who will use IFI funds in the operations relevant to crops only. The funds shall be used only for the expenses incurred in sowing and growing the crops until the final sale takes place. The operating period shall depend upon the requirements of a given crop as per the customary practices, as for Muzara'ah no fixed time period can be given. The funding shall not be used for nondirect expenses, such as marketing and storage. However, the funds may be used for machines which are subject to liquidation at the end of Muzara'ah period. Operating expenses refer to the activities up to the gross profit level, which include purchase of seeds, materials and equipment, as well as technological costs, processing/manufacturing, and the sale of crops to earn gross revenue which comes after the deduction of the cost of goods sold from sales/revenues. The important factor to consider here is that the fixed assets are subject to evaluation and to be taken by the partners according to the contribution.

- The IFI funding will be given a specific weightage in order to calculate until the crops are sold. The weightage will be fixed for the whole duration of facility.

- The farmer will be given a Muzara'ah financing limit of, for instance, USD I,000,000 for a year.

- Based on this limit, the IFI will open a Muzara'ah account for the farmer, from which the farmer will withdraw funds, as per her or his requirements, up to the limit, and use the same for growing and selling the crops. The farmer may start to return the funds to the account at any point of time. This means that during the term of the facility, the farmer will withdraw and return funds from time to time (not exceeding the limit at any time) and use the same in his or her business as per liquidity requirements. The calculation of profit on the return and withdrawal will be done as per agreed weightages or as per provisional profit rate, as mentioned in next point; however, this provisional profit is subject to adjustment with actual/realized profit.

- At the end of each calendar quarter during the calendar year, the farmer will pay the provisional profit, as mentioned above, to the bank based on the expected profit rate applied to the bank's funds outstanding at the end of each day. However, this will only be a provisional profit payment, to be adjusted based on actual results at the end of the year or crop sale or whatever the termination date of the agreement is.

- At the end of the tenure, the IFI will calculate the bank's investment in the crop production on a daily product basis, that is, the end-of-day outstanding balances (the balance of funds utilized by the customer at the end of each day). The formula for this will be as follows:

- (IFI funding in Muzara'ah for the Period = (IFIF End of Day Outstanding Balances in Muzara'ah Account divided by No of Days in the Muzara'ah period.) 
- The IFI funding shall be multiplied by the IFI funding weightage (stated in the legal agreement) to calculate the weighted average investment.

- After harvesting, the crops will be delivered and sold on the market. The gross profit earned through the sale of crops is the actual profit for distribution.

- Settlement of actual and provisional profit shall be made and an adjustment of the same shall be passed on.

\subsection{Some Necessary Conditions for the Model}

Based on the above research, this model requires that the following conditions must be met.

- The parties must be competent to enter into a Muzara'ah contract.

- An agreement on the distribution and sharing gross profit is made. Distribution means who will contribute while sharing gross profit means the agreement on gross revenue in kind or in money; for example the crops can be shared when ready or the amount can be shared when crops are sold.

- It is advisable that the IFI should contribute the fixed assets while other party provides the seeds and manages the farming. This is important as Muzara'ah is liquidated automatically when the crops are ready to be sold. So, in this case the fixed assets are returned to respective partners for onwards use.

- If the farmer has land and management skills, or a landlord has management skills, then this is a straightforward case; however, if a farmer does not have land, there may be two options. The first is that the IFI can execute a tripartite agreement the landlord, farmer and itself with an agreement on the sharing ratio and return of land to the landlord. In another scenario, IFI can get a land on lease from the landlord and government, and execute a Muzara'ah agreement with the farmer. However, in this case the landlord will not be part of the gross profit sharing. It is also important that the land is free from the landlord for the farmer to work independently.

- Offer and acceptance must be clearly expressed and agreed upon by the parties.

- Land must be available and the owner must move off the land so that the farmer can work unimpeded in all the scenarios.

- The crop to be cultivated must be specified.

- The period of the Muzara' ah is to be determined by the custom/nature of crops.

- The kind of seeds to be sown must be specified; the seeds may be provided by the owner of the farm according to the prevailing norm.

- The farmer is a trustee and is not liable for damage to or loss of the crop, except in the case of an excess of authority, default or a violation of the Muzara'ah conditions.

- If there is no crop produced on the land due to natural hazards, the farmer will not be liable to compensate the landlord. This is because the contract is a sharing in nature and is not a hiring or leasing arrangement.

- It is invalid to stipulate a specific amount of the produce for either partner, because that may hinder the realization of a partnership.

- In the event of crop failure, neither shall get anything. The farmer loses the effort and the landowner loses the utility of the land.

- The contract comes to an end explicitly or implicitly. Express termination is by faskh or iqāla (negotiated rescission). Termination by act is when the access to the land is denied or when the period of the Muzara'ah is over. It is also terminated by the death of the farmer/managing partner; however, the rights will pass to the heirs. If the landlord dies, the farmer will continue until the produce is harvested, and the new landlord cannot evict her or him.

- A Muzara'ah contract can also be terminated if the IFI goes bankrupt by incurring a heavy debt that necessitates the land to be liquidated after harvesting the produce to save the working farmer from losing her or his share. Another way it can be terminated is by completing the period of Muzara'ah or by harvesting the maize or by foregoing one's right/share from the parties to Muzara'ah or if the farmer refuses to work on the land, provided that doing this will not cause any loss to the landowner.

- IFIs may look at the Muzara'ah-based options if it suits their organizational and operational requirements, subject to compliance with the Islamic guidelines in general and the guidelines of their Shari'a Supervisory Boards in particular. Islamic banks should also ensure that the relevant staff possess the requisite knowledge and expertise. The best way of ensuring this will be to launch awareness campaigns through electronic and print media, seminars and workshops to ensure that their customers, who happen to be mostly farmers, are fully educated about the model and familiar with requirements such as documentation, financing limits, process flows, procedures, etc. Such awareness is vital because this model departs from the lending model under which banks lend without actually participating and are mostly concerned about the repayment of loans. Under Muzara'ah, the repayment plan is dependent upon the final production. 
- Under the proposed Muzara'ah model, farmers may, at their discretion, enter into single or multiple Muzara'ah transactions based on their specific funding needs. The Muzara'ah funds needed by the farmer will be disbursed/credited to the farmer's account as a lump sum.

\subsection{Socio-Economic Impact of The Model}

Based on the model presented above, this model has a positive impact on the socio-economic activities as the model has an inbuilt element of socio-economic participation. Some of the benefits of this model is as under:

- There is a debt-based sources of financing which is inadequate to agriculture sector. The land tenure system is also a hurdle challenge in the growth of agricultural sector. The farmers who own land cannot do the farming by themselves, the farmers who have skills but do not have land, and the farmers who have land and skills but do not have funding to do farming. This model is including all above under one umbrella along with the essence of participation which will lead to an economic growth in this sector, reducing unemployment, rural development.

- The model will help the Islamic Financial institutions and state-owned enterprises focusing on agricultural development to develop set of rules and regulations for an effective implementation of the model.

- Muzara'ah has unique characteristics through which can assist agricultural sector by by providing lands from the landowners and/or the government land to the landless farmers and employ their labor which helps in alleviating poverty, creating job opportunities, achieve macroeconomic growth.

- The model will also help Islamic Financial institutions to shift their focus from debt-based modes of financing towards participatory sharing-based modes of financing.

Therefore, above study strongly recommends that governments at all levels, ministries, commissions for agriculture, and financial institutions through the guidance and regulation of the Central Bank of Nigeria (CBN) should design and adopt a policy framework on PX]DUD[DK comprising rules and regulations on access to land, terms and conditions of the contract, and modus operandi and also laws concerning disputes resolution for the successful establishment of the contract and alleviation of rural poverty as proved by the empirical studies.

\subsection{Limitations of the Study}

The present study is composed of only a sample of farmers, landlords and Islamic bankers from a limited area. A bigger sample could have presented a better result. The study also does not use complex quantitative inferences.

\subsection{Future Research}

Further research can be carried out on the impact of such models in other sectors. Some possible avenues for its use can be the areas of infrastructure development, wind and solar energy system, mining, and so forth.

\section{References}

Accounting \& Auditing Organization for Islamic Financial Institutions AAOIFI. (2015). Manama. Retrieved from www.aaoifi.com

Ahmad, K \& Rana, AW. (2009). Application of Islamic banking instrument (Bai Salam) for agriculture financing in Pakistan. British Food Journal 3, 275-292.

Aleem, I. (1990). Imperfect information, screening, and the costs of informal lending: a study of a rural credit market in Pakistan. World Bank Economic Review, 4(3), 329-49.

Al-Harran SA. (1990) Islamic Finance: The Experience of the Sudanese Islamic Bank in Partnership (Musharakah) Financing as a Tool for Rural Development among Small Farmers in Sudan. Durham E-Theses, Durham University, UK

Al-Qurafi, S. (I285/684AH / 1994). Al-Dhakhirah fi Fiqh Alim al-Medinah. 6, I25-9. First Edition Dar al-Gharb al-Islami

Business Recorder. (20I I). Pakistan Agriculture. Retrieved from https://fp.brecorder.com/20I I/06/20I I0630I207I I2

Donaldson, W. J. (2000). Sharecropping in the Yemen: A Study in Islamic Theory, Custom and Pragmatism. Leiden, Boston \& Koln: Brill.

Kahf, M. (2015). Islamic Finance Contracts. Retrieved from http://kahf.com/blog/2015/09/02/islamic-finance-contracts/

Mohsin, MI. (2005). The practice of Islamic banking system in Sudan. Journal of Economic Cooperation, 26, (4), 27-50

Rahman, AA. (2012.) The Agricultural Land Tenancy Contract from the Islamic Perspective and its Practice among Farmers: A study in Selangor, Malaysia. African Journal of Agricultural Research 7(I0), I584-I594.

Nyazee, I. A. K. (2002). Islamic law of business organization partnerships. International Institute of Islamic Thought (IIIT).

Pakistan Bureau of Statistics. (2020). Agriculture Statistics. Retrieved from http://www.pbs.gov.pk/content/agriculturestatistics

Pakistan Economic Survey 2017-I8. (2018). Retrieved from http://www.finance.gov.pk/survey/chapters_I8/02Agriculture.pdf

Raza, M, Saeed, A \& Shahid, SM. (2013). Impact of Low-Sugar-Cane yield on Sugar Industry of Pakistan. IJCRB, 5(I2). 
Pakistan Economic and Development Strategy Handbook. (2007). USA International Business Publications. Sarkhasi Shamsuddeen, (n.d). Kitab al-Mabsoot. PP.I-I60. Dar al-Fajr. Beirut,

Shafiai, M. H. B. M. (20I I). Theory of" Sharecropping" from an Islamic Economic Perspective: A Study of al-Muzāra a \& alMusāqāt. Kyoto Bulletin of Islamic Area Studies, 4(I\&2), I90-209.

Shīrāzī, Abū Isḥāq Ibrāhīm ibn 'Alī ibn Yūsuf al-Fīrūzābādī. (I959). Al-Muhadhdhab fī Fiqh al-Imām al-Shāfiłī, vol. I. Miṣr: Maktaba Musțafā al-Bābī al-Ḥalabī wa-Awlāduhu.

Haque, Z. (1984). Landlord and peasant in early Islam: a study of the legal doctrine of "Muzāra 'a or sharecropping". Islamic Research Inst..

\section{Appendix A - Questionnaire}

Questionnaire No.: ___ Date of Interview:

Gender of the respondent: Male (All the respondent are male as females are not involved in farming activities)

Q I. Respondent status (farmer/landlord/both, etc.)

Q2. Age of respondent

Q 3. Education level

Q 4. How many years have you been associated with this activity?

Q 5. Do you sell all the crops produced?

- Yes

- No

- Other

Q 6. How do you transport the goods to Mandi (where it can be sold)?

- By myself

- In rented transport

Q 7. Has your business been profitable in the last 3 years?

- Yes

- No

- Other

Q 8. Is the profit enough? Huge? Average?

- Yes

- No

- Other

Q 09. What is the main source of water for these farms?

- Rain

- Local irrigation supply water

- Other

Q I0. How many growing cycles do you have per year?

- I

- 2

- 3

QII. How many months does each growing cycle last?

- months

- 6 months

- I year

QI2. Do you have a savings account with a financial institution?

- Yes

- No

Q13. In your opinion, if you want to get a loan from a financial institution, how important are the following factors? (Rate from I to 5 , with I being least important and 5 the most important):

- Quick disbursement of loan (quick processing of loan application) I 2345

- Low interest rate/cost of borrowing I 2345

- Convenient repayment period I 2345

- Absence of requirement for collateral I 2345 
QI4. Have you applied for a loan from a financial institution in the previous five years?

- Yes

- No

Q I5. What are the reasons that you have not applied for a loan with a financial institution?

- Primary reason: Riba (Interest)

- Secondary reason: Excessive collateral requirements

- Tertiary reason: High costs associated with borrowing

- Other (please specify, e.g., I can borrow from friends)

Q I6. Have you received a loan from informal sources, such as family and friends?

- Yes

- No

Q 17. Why do you need money?

- To purchase seeds/goods for sale

- To purchase ploughing assets (buildings, equipment, livestock)

- To purchase agricultural products (seeds, fertilizer, pesticides, animal feed, etc.)

- Other

Q 18. Would you apply to an Islamic banking entity for funding?

- Yes

- $\mathrm{No}^{-}$

- Don't know

The following questions were put to respondents who do not have land.

Q I9. Do you have a crop sharing arrangement with the landlord? If yes, select below:

- Fixed return paid to landlord in advance

- Profit sharing agreement

- Landlord provides money in advance

Q 20. Do you know of Muzara'ah? If yes, please describe this arrangement.

Q.2I. In the event of any natural mishap, who is responsible?

- Landlord, fully

- Farmer, fully

- Both, jointly

- Other

Q.22 what is your view of the Islamic model of Muzara'ah? (Here, the author explained the model to each farmer.)

- Like

- Dislike

- No idea

- Q.23 Would you like to obtain financing based on the concept of the Islamic model of Muzara'ah?

- Yes

- No

Q. 24 Does bad weather have any impact on production on your land? If yes, which has the highest impact?

- Rain

- Snow

- Heatwave

Q. 25. Do any natural risks commonly adversely affect maize farms? Please list them.

Q. 26. Do you suffer from market price changes?

- Yes

- No

Q. 27 Do you use the latest technology?

- Yes

- No

The two questions below were put to landlords who do not do any work, but just provide their lands to farmers. 
Q. 28. Would you accept the Islamic mode of sharecropping (Muzara'ah)?

- Yes

- No

- Don't know

Q. 29 On what basis does the local Muzara'ah work?

- Fixed output to be provided to landlord

- $\quad$ Fixed money to be provided to landlord

- Fixed part of produce to be provided to landlord

- $\quad$ Sharecropping based upon PLS mechanism

The following three questions were only put to the Islamic bankers.

Q. 30. Is your bank interested in financing this sector?

- Yes

- No

- Don't know

Q. 3I. Will your bank finance farmers have based upon personal guarantees or any other security other than a mortgage as collateral?

- Yes

- No

- Don't know

Q 32. Will your bank finance farmers have based upon the Islamic model of Muzara'ah?

- Yes

- No

- Don't know

\section{Appendix B - Responses}

\begin{tabular}{|c|c|}
\hline S. No & Questions and Results \\
\hline \multirow[t]{7}{*}{ I } & $\begin{array}{l}\text { Has your business been profitable in the last } 3 \text { years? } \\
\text { Yes: } 80 \% \\
\text { No: } 18 \% \\
\text { Other: } 02 \% \text { (no profit no loss) }\end{array}$ \\
\hline & 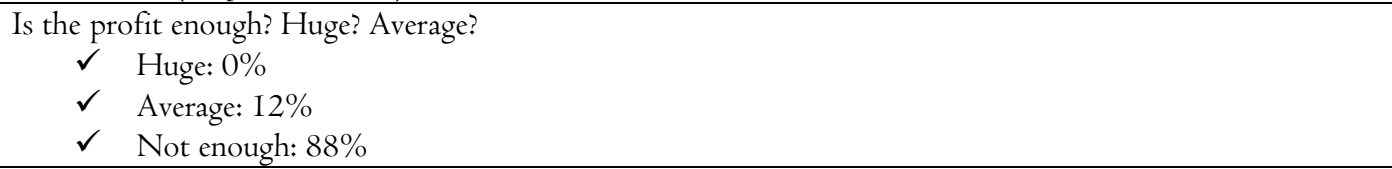 \\
\hline & 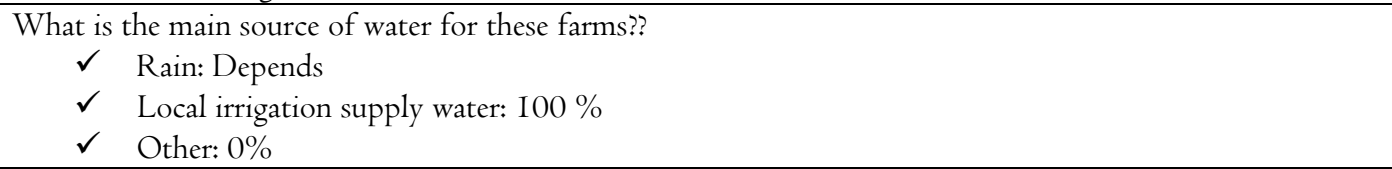 \\
\hline & $\begin{array}{l}\text { Do you have a savings account with a financial institution? } \\
\qquad \begin{aligned} \checkmark & \text { Yes: } 30 \% \\
\checkmark & \text { No: } 70 \%\end{aligned}\end{array}$ \\
\hline & $\begin{array}{l}\text { In your opinion, if you want to get a loan from a financial institution, how important are the following } \\
\text { factors? } \\
\square \quad \text { Quick disbursement of loan: } 28 \% \\
\square \quad \text { Low interest rate/cost of borrowing: } 0 \% \\
\square \quad \text { Convenient repayment period: } 0 \% \\
\square \quad \text { Absence of requirement for collateral: } 72 \%\end{array}$ \\
\hline & $\begin{array}{l}\text { Have you applied for a loan from a financial institution in the previous five years? } \\
\qquad \begin{array}{l}\checkmark \\
\checkmark\end{array} \text { Yes: } 24 \% \\
\quad \text { No: } 76 \%\end{array}$ \\
\hline & $\begin{array}{l}\text { What are the reasons that you have not applied for a loan with a financial institution? } \\
\square \quad \text { Riba (interest is disallowed as per religion): } 58 \%\end{array}$ \\
\hline
\end{tabular}




\begin{tabular}{|c|c|}
\hline & $\begin{array}{l}\text { Excessive collateral requirements: } 38 \% \\
\text { High costs associated with borrowing: } 0 \% \\
\text { Other (please specify) - no need: } 4 \%\end{array}$ \\
\hline \multicolumn{2}{|r|}{$\begin{array}{l}\text { Have you received a loan from informal sources, such as family and friends? } \\
\square \quad \text { Yes: } 50 \% \\
\quad \text { No: } 50 \%\end{array}$} \\
\hline \multicolumn{2}{|r|}{ 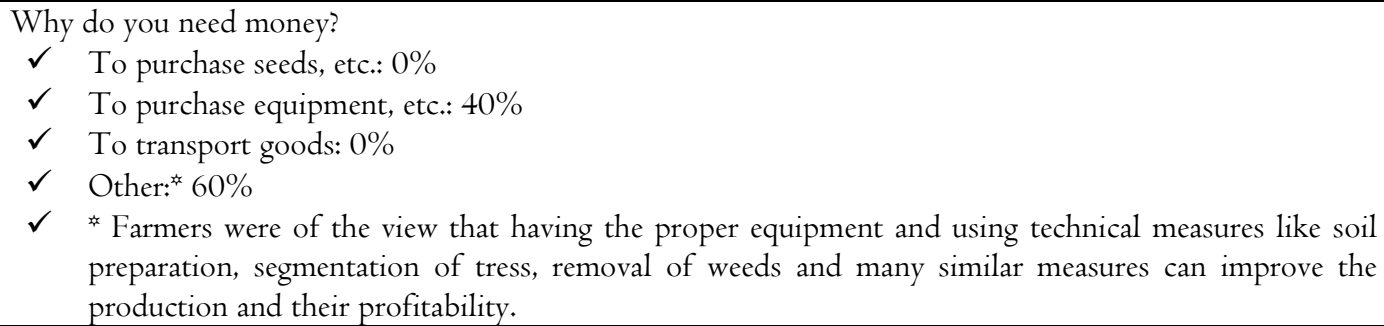 } \\
\hline \multicolumn{2}{|r|}{ 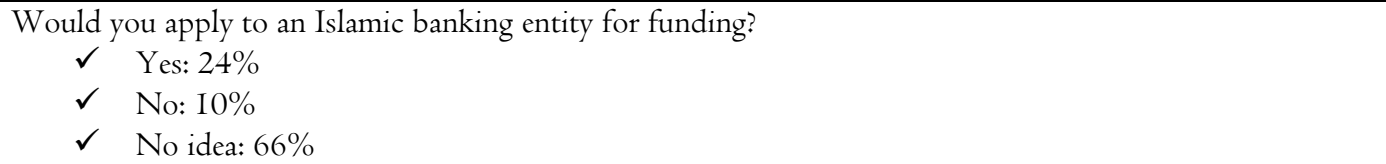 } \\
\hline \multicolumn{2}{|r|}{$\begin{array}{l}\text { Do you have a crop sharing arrangement with the landlord? If yes, select below: } \\
\square \quad \text { Fixed return paid to landlord in advance: } 92 \% \\
\quad \text { Profit sharing agreement: } 8 \%\end{array}$} \\
\hline \multicolumn{2}{|r|}{$\begin{array}{l}\text { Do you know of Muzara'ah? If yes, is it: } \\
\square \quad \text { Fixed return paid to the landlord in advance: } 100 \% \\
\quad \text { Profit sharing agreement: } 0 \%\end{array}$} \\
\hline \multicolumn{2}{|r|}{ 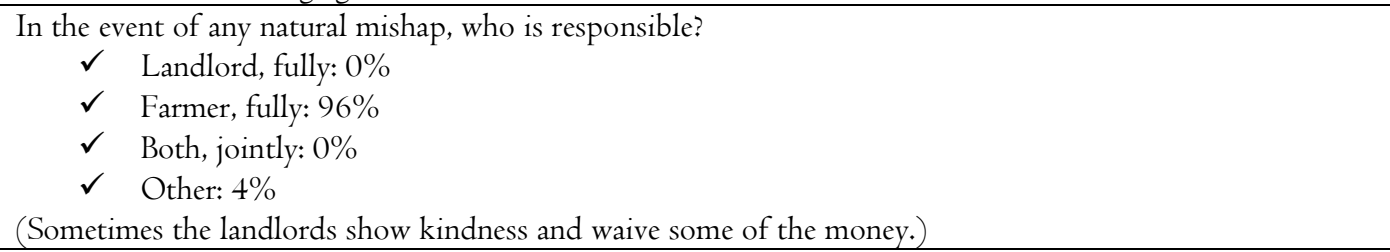 } \\
\hline \multicolumn{2}{|r|}{$\begin{array}{l}\text { What is your view of the Islamic model of Muzara'ah? } \\
\checkmark \quad \text { Liked: } 80 \% \\
\checkmark \quad \text { Disliked: } 0 \% \\
\checkmark \quad \text { Any other: } 20 \% \text { consider it not practical }\end{array}$} \\
\hline \multicolumn{2}{|r|}{ 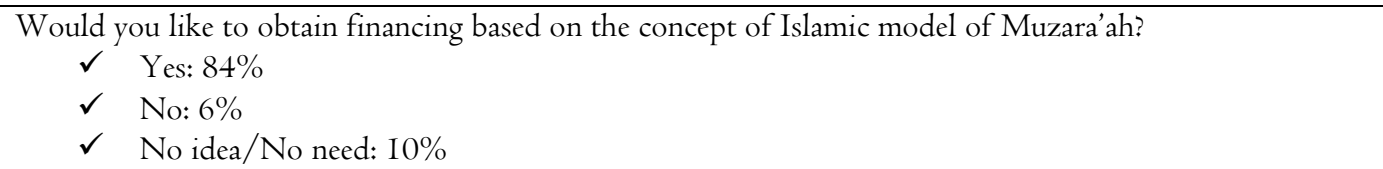 } \\
\hline \multicolumn{2}{|r|}{$\begin{aligned} & \text { Does bad weather have any impact on production? If yes, which has the highest impact? } \\
& \checkmark \text { Rain: 0\% } \\
& \checkmark \text { Snow (hailing): } 100 \% \\
& \checkmark \text { Heatwave: } 0 \%\end{aligned}$} \\
\hline \multicolumn{2}{|r|}{$\begin{array}{l}\text { Does any natural risk commonly adversely affect maize farms? } \\
\text { I00\% said that moonlight can also damage the crops }\end{array}$} \\
\hline \multicolumn{2}{|r|}{$\begin{array}{l}\text { Do you suffer from market price changes? } \\
\square \quad \text { Yes: } 15 \% \\
\square \quad \text { No: } 10 \% \\
\square \quad \text { No visible impact: } 75 \%\end{array}$} \\
\hline \multicolumn{2}{|r|}{$\begin{array}{l}\text { Q. } 25 \text { Do you use the latest technology? } \\
\checkmark \quad \text { Yes: } 0 \% \\
\checkmark \quad \text { No: } 100 \%\end{array}$} \\
\hline \multicolumn{2}{|r|}{$\begin{array}{l}\text { The two questions below were put to landlords who do not do any work, but just provide their lands to } \\
\text { farmers. } \\
\text { Would you accept the Islamic model of sharecropping (Muzara'ah)? }\end{array}$} \\
\hline
\end{tabular}




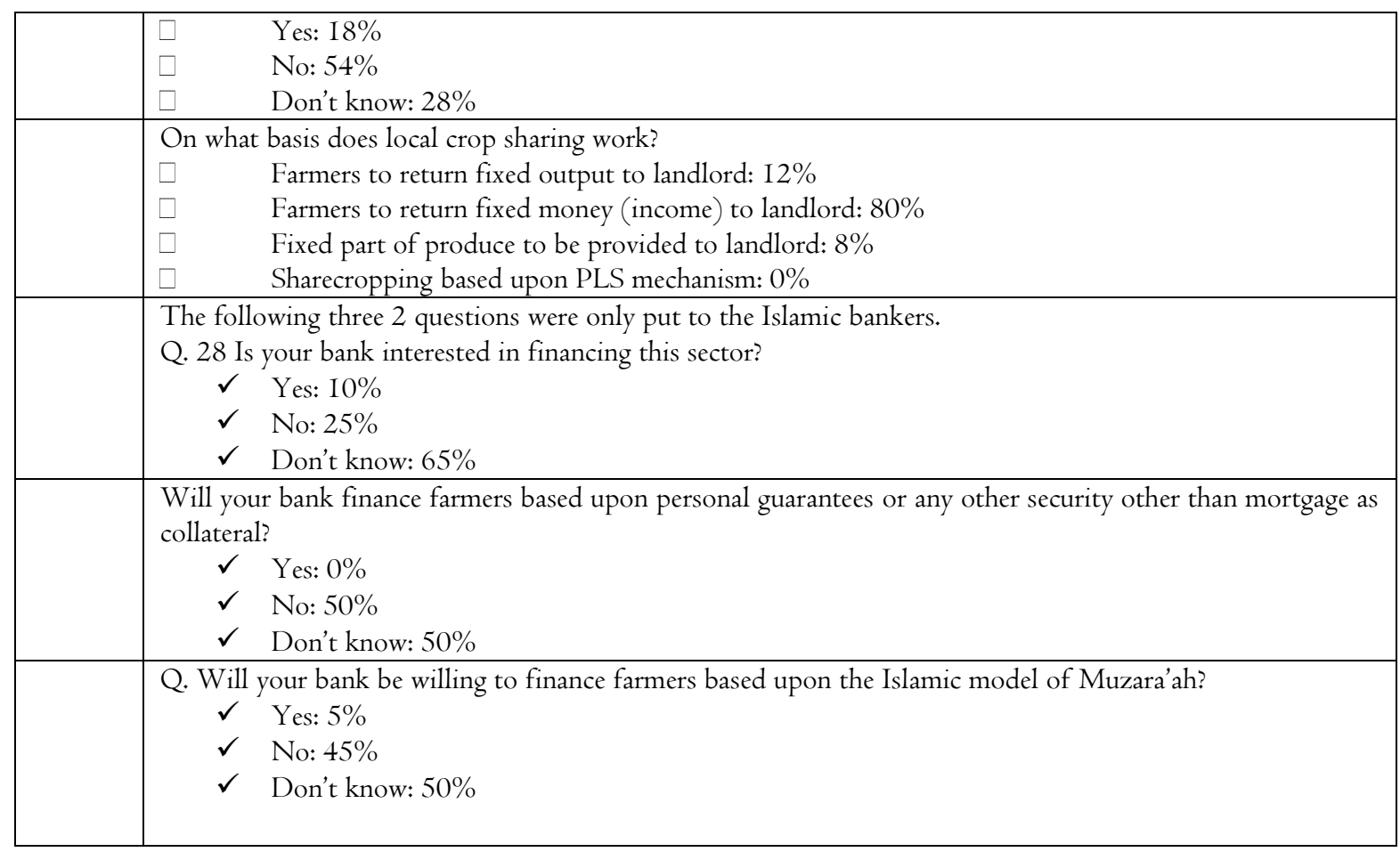

\section{Copyrights}

Copyright for this article is retained by the author(s), with first publication rights granted to the journal. This is an open-access article distributed under the terms and conditions of the Creative Commons Attribution license (http://creativecommons.org/licenses/by/4.0/). 